\title{
Peningkatan Hasil Belajar Qur'an Hadist Melalui Model Pembelajaran Kooperatif Tipe Talking Stick Pada Siswa MTs Al-Huda Kota Gorontalo Tahun pelajaran 2019/2020
}

\author{
Nurliyan Hulawa \\ Guru MTS Al-Huda Kota Gorontalo \\ nurliyan@gmail.com
}

Received: 04 March 2021; Revised: 26 April 2021; Accepted: 28 August 2021

DOI: http://dx.doi.org/10.37905/aksara.7.3.1117-1122.2021

\begin{abstract}
ABSTRAK:
Tujuan dari penelitian adalah untuk meningkatkan hasil belajar peserta didik kelas IX MTS Al-Huda Kota Gorontalo pada mata pelajaran Qur'an Hadist. Penelitian yang dilakukan menggunakan penelitian tindakan kelas dengan sujek penelitian siswa kelas IX MTS Al-Huda Kota Gorontalo.

Hasil dari penelitian ini penggunaan model pembelajaran kooperatif tipe talking stick dapat meningkatkan kualitas pembelajaran, baik menyangkut kegiatan guru, aktivitas peserta didik dalam pembelajaran, serta berdampak pada peningkatan hasil belajar peserta didik kelas IX MTS Al-Huda Kota Gorontalo. Hal ini dapat dilihat pada hasil yang dicapai berikut ini : a) Aktivitas guru mengalami peningkatan, dari siklus I sebesar $76.92 \%$ yang terlaksana meningkat pada siklus II sebesar $100 \%$ yang terlaksana. b) Aktivitas peserta didik mengalami peningkatan, dari siklus I sebesar 54,54\% yang tuntas meningkat pada siklus II sebesar $100 \%$ yang tuntas. c) Hasil belajar peserta didik mengalami peningkatan, dari siklus I sebesar $71,75 \%$ yang tuntas meningkat pada siklus II sebesar $100 \%$ yang tuntas
\end{abstract}

\section{Kata Kunci : Qur'an Hadits, tipe talking stick, hasil belajar}

\section{PENDAHULUAN}

Keberhasilan sebuah proses belajar mengajar sangat ditentukan oleh hasil belajar yang dicapai oleh peserta didik. Ketuntasan hasil belajar ini menjadi cermin dari keberhasilan guru dalam menerapkan metode pembelajaran, dan hasil belajar yang dicapai peserta didik sangat dipengaruhi oleh cara belajar peserta didik itu sendiri.

Pembelajaran Qur'an Hadist di Madrasah Aliyah hendaknya membuka kesempatan untuk memupuk rasa ingin tahu peserta didik secara alamiah. Hal ini akan membantu peserta didik mengembangkan kemampuan bertanya dan mencari jawaban atas fenomena alam berdasarkan bukti serta mengembangkan cara berfikir ilmiah.

Fokus program pengajaran Agama Islam hendaknya ditujukan untuk memupuk minat dan pengembangan peserta didik terhadap dunia mereka di lingkungan mereka hidup. Melalui pembelajaran Agama Islam, peserta didik diajak untuk mengamati alam dan mencari tahu serta mengenal lingkungan sekitar.

Namun kenyataan di lapangan tidak seperti itu. Pembelajaran yang dilakukan guru, selama ini masih menggunakan metode ceramah, sehingga pembelajaran hanya berfokus pada guru. Metode ini menyebabkan peserta didik tidak aktif selama proses 
pembelajaran, sehingga peserta didik tidak dapat mengembangkan materi yang seharusnya bisa dikembangkan melalui diskusi-diskusi dalam kelompok.

Permasalahan yang dihadapi di Kelas IX MTS Al-Huda Kota Gorontalo, khususnya pembelajaran Qur'an Hadist adalah kurangnya partisipasi pendidikan Qur'an Hadist dan respon peserta didik pada proses pembelajaran. Hal ini nampak pada kurangnya perhatian peserta didik pada saat guru menjelaskan, kurangnya kemampuan peserta didik dalam memecahkan soal-soal latihan, rendahnya hasil yang dicapai peserta didik pada evaluasi, serta kurangnya kemauan peserta didik untuk mengajukan pertanyaan maupun menjawab pertanyaan yang diajukan guru. Keadaan tersebut berpengaruh pada hasil ulangan harian yang diperoleh peserta didik, yang berimbas pada ketuntasan hasil belajar yang tidak sesuai dengan kriteria ketuntasan yang telah ditetapkan, yakni 75. Hal ini disebabkan oleh kurangnya motivasi dan keaktifan peserta didik dalam belajar. Proses pembelajaran menggunakan metode ceramah menyebabkan peserta didik menjadi bosan dalam menerima pelajaran, sehingga berdampak pada hasil belajar yang dicapai oleh peserta didik.

Upaya yang dapat dilakukan untuk mengatasi hal tersebut adalah mengembangkan kurikulum, mengembangkan kualitas pembelajaran, peningkatan mutu tenaga pengajar, serta lingkungan belajar yang kondusif dan memadai (Prabowo, 2001: 75). Metode talking stick adalah salah satu metode pembelajaran yang dapat diterapkan, yaitu suatu metode pembelajaran dengan menggunakan tongkat sebagai alat bantu. Metode ini melatih peserta didik untuk berfikir cepat dalam pembelajaran sekaligus mengasah kemampuan peserta didik melalui pertanyaan-pertanyaan yang diberikan guru. Pada metode talking stick, peserta didik yang memegang tongkat wajib menjawab pertanyaan dari guru setelah peserta didik mempelajari materi pokok. Dengan memilih metode talking stick, diharapkan peserta didik selalu siap setiap pembelajaran, sehingga berdampak pada meningkatnya hasil belajar yang dicapai peserta didik.

Berdasarkan uraian latar belakang di atas, peneliti bermaksud melakukan Penelitian Tindakan Kelas dengan judul "Upaya Meningkatkan Hasil Belajar Qur'an Hadist Melalui Penggunaan Model Pembelajaran Kooperatif Tipe Talking Stick pada Peserta Didik Kelas IX MTS Al-Huda Kota Gorontalo.

\section{METODE PENELITIAN}

Penelitian Tindakan Kelas ini dilaksanakan di MTS Al-Huda Kota Gorontalo. Peserta didik yang dikenai tindakan adalah peserta didik kelas IX, dengan jumlah peserta didik sebanyak 20 orang, terdiri dari 7 peserta didik laki-laki dan 9 peserta didik perempuan. Penelitian ini adalah penelitian bersiklus. Jika pada siklus 1 hasilnya tidak sesuai dengan standar ketuntasan, maka akan dilanjutkan pada siklus selanjutnya.

Berbagai tindakan yang direncanakan dalam pembelajaran Qur'an Hadist dilakukan dengan menggunakan model kooperatif tipe talking stick. Pelaksanaan tindakan yang dilakukan peneliti berdasarkan rancangan yang telah ditetapkan dan disusun sebelumnya, sebagaimana dalam Skenario Pembelajaran.

Data tentang hasil pengamatan kegiatan guru, yang diperoleh melalui check list dan data hasil belajar yang diperoleh melalui tes hasil belajar dianalisis melalui tiga tahap, yaitu reduksi data, paparan data, dan penyimpulan. 
AKSARA: Jurnal Ilmu Pendidikan Nonformal

P-ISSN 2407-8018 E-ISSN 2721-7310 DOI prefix $\underline{10.37905}$

Volume 07, (03) September 2021

http://ejurnal.pps.ung.ac.id/index.php/Aksara

\section{HASIL DAN PEMBAHASAN}

Pelaksanaan penelitian serta pengambilan data pada pertemuan 1 dan pertemuan 2 siklus I dilakukan secara bersama-sama oleh peneliti dan dua orang observer. Pada pertemuan ini peserta didik dibelajarkan dengan menggunakan model pembelajaran kooperatif tipe talking stick. Sebelum memulai pembelajaran, guru memberikan petunjuk tentang cara bermain tongkat. Pada kegiatan pembelajaran, peserta didik yang memperoleh tongkat diwajibkan menjawab pertanyaan yang diajukan guru, dan sebelum pembelajaran ditutup, peserta didik diberikan pekerjaan rumah.

Uraian data menunjukkan bahwa dari 13 aspek kegiatan guru yang diobservasi pada siklus I, 38,46\% mencapai kategori sangat baik (SB), 38,46\% mencapai kategori baik (B) dan 23,08\% mencapai kategori cukup (C). Total kategori sangat baik dan baik mencapai 76,92\%. Hasil ini belum mencapai kriteria ketuntasan yang diharapkan, yaitu $80 \%$. Pada hasil menunjukkan bahwa dari 11 aspek aktivitas peserta didik yang diobservasi pada siklus I, 4,55\% mencapai kategori sangat baik (SB), 45,45\% mencapai kategori baik (B) dan 50\% mencapai kategori cukup (C). Total kategori sangat baik dan baik mencapai $50 \%$. Hasil ini belum mencapai kriteria ketuntasan yang diharapkan, yaitu $80 \%$.. Untuk mengetahui hasil belajar peserta didik pada kelas IX MTS Al-Huda Kota Gorontalo pada materi Kalor yang telah dibelajarkan, maka pada akhir pembelajaran siklus I dilakukan evaluasi yang terdiri dari 5 tes essai dengan skor maksimum 100, sedangkan untuk ketuntasan individu ditetapkan nilai capaian, yaitu nilai 76 ke atas.

Dari 16 orang peserta didik yang dikenai tindakan, 13 orang (65\%) dinyatakan tuntas pada materi Kalor dan pengaruhnya terhadap perubahan suhu dan wujud zat pada siklus I, karena telah mencapai skor minimum yang ditetapkan, yaitu 76 ke atas. Sebaliknya, terdapat 7 orang (35\%) dinyatakan tidak tuntas, karena tidak mencapai skor minimum yang ditetapkan. Hasil belajar peserta didik tersebut menunjukkan bahwa indikator keberhasilan belum dapat dicapai. Dari hasil analisis diketahui terdapat beberapa aspek kegiatan guru dan aktivitas peserta didik pada siklus I yang belum optimal dan memperoleh kategori cukup (C).

Siklus II membahas materi Perpindahan kalor dan manfaatnya dalam kehidupan sehari-hari, yang dilaksanakan dalam satu kali pertemuan. Pembelajaran materi pada siklus II mengacu pada Rencana Pelaksanaan Pembelajaran (RPP).

Pelaksanaan penelitian serta pengambilan data pada siklus II dilakukan secara bersama-sama oleh peneliti dan dua orang guru mitra. Pada pertemuan ini peserta didik dibelajarkan dengan menggunakan model pembelajaran kooperatif tipe talking stick. Sebelum memulai pembelajaran, guru memberikan petunjuk tentang cara bermain tongkat. Pada kegiatan pembelajaran, peserta didik yang memperoleh tongkat diwajibkan menjawab pertanyaan yang diajukan guru, dan sebelum pembelajaran ditutup, peserta didik diberikan pekerjaan rumah.

Kegiatan analisis ini diikuti pula dengan kegiatan refleksi. Dari refleksi yang dilakukan dapat diketahui bahwa seluruh aspek kegiatan guru dan aktivitas peserta didik pada siklus II sudah optimal dan memperoleh kategori observasi sangat baik (SB) dan baik (B). Dengan hasil tersebut berarti penelitian tindakan kelas yang menyajikan konsep Kalor, yang dibelajarkan melalui model pembelajaran kooperatif tipe talking stick telah berhasil meningkatkan hasil belajar siswa kelas IX MTS Al-Huda Kota Gorontalo.

Proses pembelajaran pada hakikatnya merupakan proses komunikasi antara guru dan peserta didik dalam rangka perubahan sikap. Karena itu, baik konseptual maupun 
operasional konsep komunikasi dan perubahan sikap selalu melekat dalam pembelajaran dan guru mutlak menguasainya. Hal ini sejalan dengan yang dikemukakan Rogers (dalam Winataputra, 1993: 22) yang memberi pengertian "komunikasi sebagai proses yang menuntut peserta didik menciptakan dan saling berbagi informasi satu sama lain guna mencapai pengertian timbal balik. Pola dasar komunikasi paling banyak diterapkan dalam situasi ketika guru menghadapi situasi klasikal massal.

Dalam menghadapi situasi klasikal berkenaan dengan penyajian konsep Kalor, di kelas IX MTS Al-Huda Kota Gorontalo serta kaitannya dengan pelaksanaan penelitian tindakan kelas, peneliti menggunakan model pembelajaran kooperatif tipe talking stick. Metode tersebut dipilih dengan pertimbangan dan alasan, serta mengacu pada pendapat yang dikemukakan oleh Kiranawati (2007) tentang kelebihan model pembelajaran kooperatif tipe talking stick, yaitu peserta didik dilatih untuk memahami materi dengan cepat sekaligus mengasah kemampuan peserta didik untuk menjawab pertanyaan dengan cepat.

Berdasarkan pertimbangan di atas, maka peneliti menggunakan model pembelajaran kooperatif tipe talking stick untuk membelajarkan konsep. Konsep tersebut dibelajarkan dalam 3 kali pertemuan dan dibagi dalam 2 siklus. Siklus I membahas tentang Energi Kalor, sedangkan siklus II membahas tentang perpindahan kalor dan manfaatnya dalam kehidupan sehari-hari.

Adapun perangkat yang digunakan untuk menunjang hasil penelitian adalah lembar pengamatan aktivitas guru, pengamatan aktivitas peserta didik, serta tes hasil belajar peserta didik. Pada siklus I, pengelolaan pembelajaran yang dilaksanakan oleh guru belum mencapai kriteria ketuntasan yang diharapkan. Aspek-aspek yang belum tuntas ini pada siklus 1 kemudian diperbaiki pada siklus II. Hasil yang diperoleh dapat dilihat pada gambar di atas. Terdapat perbedaan yang signifikan antara kegiatan guru pada siklus I dan siklus II.

Rendahnya aktivitas peseta didik pada siklus I disebabkan oleh kurangnya interaksi antar peserta didik, kerja sama antar peserta didik, kemampuan memberikan gagasan/ide pokok, kemandirian belajar, dan membuat kesimpulan materi. Hal ini kemudian diperbaiki pada siklus II, sehingga aktivitas peserta didik pada siklus II meningkat.

Berdasarkan hasil penelitian, diperoleh bahwa metode talking stick dapat meningkatkan hasil belajar peserta didik. Hal ini berdasarkan hasil yang diperoleh pada Siklus I dan Siklus II, yang menunjukkan peningkatan hasil belajar peserta didik

Hasil capaian peserta didik sebagaimana diuraikan di atas sekaligus menunjukkan bahwa hipotesis tindakan yang menyatakan: Jika pada mata pelajaran Qur'an Hadistdi kelas IX MTS Al-Huda Kota Gorontalo diterapkan model pembelajaran kooperatif tipe talking stick, maka hasil belajar peserta akan meningkat, diterima.

\section{PENUTUP}

Berdasarkan hasil penelitian dan pembahasan dapat disimpulkan bahwa penggunaan model pembelajaran kooperatif tipe talking stick dapat meningkatkan kualitas pembelajaran, baik menyangkut kegiatan guru, aktivitas peserta didik dalam pembelajaran, serta berdampak pada peningkatan hasil belajar peserta didik kelas IX MTS Al-Huda Kota Gorontalo. Hal ini dapat dilihat pada hasil yang dicapai berikut ini. a) Aktivitas guru mengalami peningkatan, dari siklus I sebesar $76.92 \%$ yang terlaksana meningkat pada siklus II sebesar $100 \%$ yang terlaksana. b) Aktivitas peserta didik 
mengalami peningkatan, dari siklus I sebesar 54,54\% yang tuntas meningkat pada siklus II sebesar $100 \%$ yang tuntas. c) Hasil belajar peserta didik mengalami peningkatan, dari siklus I sebesar 71,75\% yang tuntas meningkat pada siklus II sebesar $100 \%$ yang tuntas.

Dengan demikian, dapat disimpulkan bahwa model pembelajaran kooperatif tipe Talking Stick dapat meningkatkan hasil belajar peserta didik kelas IX MTS Al-Huda Kota Gorontalo.

\section{DAFTAR PUSTAKA}

Daryanto. 2001. Evaluasi Pendidikan. Rineka Cipta: Jakarta

Dimyati dan Mudjiono. 2001. Belajar dan Pembelajaran. Rineka Cipta: Jakarta

Harjanto. 2008. Perencanaan Pengajaran. Rineka Cipta: Jakarta

Hamalik Oemar. 2009. Perencanaan Pengajaran Berdasarkan Pendekatan Sistem. Bumi Aksara: Jakarta

Kiranawati. 2007. Metode Pembelajaran Talking Stick. http://gurupkn.wordpress. com/2007/12/01/talking-stick/. Tanggal 1 Desember 2007

Muhfida. 2009. Model Pembelajaran. http://www.muhfida.com/model pembelajaran.html. tanggal 4 Juli 2009

Popham W. James dan Eva L. Baker. 2005. Teknik Mengajar Secara Sistematis (Terjemahan: Amirul Hadi, dkk). Rineka Cipta : Jakarta

Slameto. 2001. Evaluasi Pendidikan. Bumi Aksara: Jakarta

Sudjana, Nana. 2004. Penilaian Hasil Proses Belajar Mengajar. Remaja Rosdakarya: Bandung

Sudjana, Nana. 2009. Penilaian Hasil Proses Belajar Mengajar. Remaja Rosdakarya: Bandung

Winataputra. 1993. Strategi Belajar Mengajar PENDIDIKAN AGAMA ISLAM. Jakarta: Depdikbud 
AKSARA: Jurnal Ilmu Pendidikan Nonformal

P-ISSN 2407-8018 E-ISSN 2721-7310 DOI prefix $\underline{10.37905}$

Volume 07, (03) September 2021

http://ejurnal.pps.ung.ac.id/index.php/Aksara

1122 AKSARA: Jurnal Ilmu Pendidikan Nonformal 